\title{
Release of Butylated Hydroxytoluene from an Active Film Packaging to Asadero Cheese and Its Effect on Oxidation and Odor Stability
}

\author{
C. D. Soto-Cantú, A. Z. Graciano-Verdugo, E. Peralta, A. R. Islas-Rubio, A. González-Córdova, \\ A. González-León, and H. Soto-Valdez ${ }^{1}$ \\ Centro de Investigación en Alimentación y Desarrollo, A.C., CTAOV, Apdo. Postal 1735, Hermosillo, Son., 83000 México
}

\begin{abstract}
Antioxidant active packaging consisting of coextruded films made of low density polyethylene (LDPE) added with 0,8 , and $14 \mathrm{mg} / \mathrm{g}$ of butylated hydroxytoluene $(\mathrm{BHT})$ and polyamide 6/66 were fabricated. The release of BHT from the films to Asadero cheese was determined. Most of the BHT was diffused from the LDPE layer to the cheese during the first $20 \mathrm{~d}$ of storage at $5^{\circ} \mathrm{C}$. Diffusion coefficient for the diffusion of BHT from the films 8 and 14 to the cheese was calculated as $6.24 \mathrm{E}-12$ and $6.26 \mathrm{E}-12 \mathrm{~cm}^{2} / \mathrm{s}$, respectively. The release of BHT from the film added with $8 \mathrm{mg} / \mathrm{g}$ of the antioxidant in the LDPE layer complied with the legal limit established for food products. However, the film added with $14 \mathrm{mg} / \mathrm{g}$ of the antioxidant exceeded that limit. The film added with $8 \mathrm{mg} / \mathrm{g}$ of BHT maintained the same levels of oxidized odor from 20 to $100 \mathrm{~d}$ of storage.
\end{abstract}

Key words: antioxidant packaging, butylated hydroxytoluene, migration, Asadero cheese

\section{INTRODUCTION}

Milk fat contains approximately $2.3 \%$ palmitoleic acid (C16:1n-7), $24.6 \%$ oleic acid (C18:1n-9), and $2.8 \%$ linoleic acid (C18:2n-6) with the last being susceptible to lipid oxidation (van Aardt et al., 2005). Asadero is a white and semihard cheese of Mexican origin with a shelf life of $60 \mathrm{~d}$ at refrigerated storage. The manufacturing process includes the use of high temperatures ( 75 to $80^{\circ} \mathrm{C}$ ) to melt the curd, to shape it with a mold, or to stretch and roll it in different shapes. During this stage the fat is concentrated and the heat applied may provoke the initiation of lipid oxidation reactions. Asadero cheese is commercially packed under vacuum with transparent barrier films. Most cheeses are packed in transparent materials and exposed to light during retail

Received June 20, 2007.

Accepted September 28, 2007.

${ }^{1}$ Corresponding author: hsoto@ciad.mx storage increasing the susceptibility for light-induced oxidation with the development of off-flavors. Volatile compounds like hexanal, heptanal, octanal, nonanal, 2-butanol, 2-pentanol, acetaldehyde, benzaldehyde, 2pentyl-furan, and tetrahydrofuran (THF) have been identified as being responsible for these unpleasant offflavors in packaged semihard cheeses (Urbach, 1993; Mortensen et al., 2002; Sunesen et al., 2002; Juric et al., 2003; Holm et al., 2006). The production of these volatile compounds is decreased by adding antioxidants (van Aardt et al., 2005).

Butylated hydroxytoluene (BHT) or 3,5-di-tert-butyl4-hydroxytoluene is a synthetic antioxidant commonly used in the food industry. The BHT is lipid soluble and terminates free-radical chain reactions by donating hydrogen atoms to free radicals producing more stable compounds. The legal limit for the addition of BHT to most foods is $200 \mathrm{mg} / \mathrm{kg}$ of fat (Code of Federal Regulations, 2007a). Usage of active packaging in contact with food is an alternative for adding antioxidants to maintain a constant concentration of the additive in the food during storage instead of adding high levels of additives directly. This beneficial role of antioxidants in packaging films has led to research in the manufacture of antioxidant-added films and their utilization in various food-packaging situations (Chick, 2002). Addition of antioxidants to polyolefins is a common practice during film manufacture because they are also used to protect low density polyethylene (LDPE) from degradation. The BHT is usually used at concentrations up to 500 $\mathrm{mg} / \mathrm{kg}$ in polyolefins (Linssen et al., 1998). During film processing, part of the antioxidant is lost because of its ability to function as a free-radical scavenger. Also, it may be lost to the environment because of its high volatility at processing temperatures (Vulic et al., 2002). Therefore, to ensure the extension of the shelf life of food susceptible to deterioration by oxidation, active packaging films must be formulated with a higher antioxidant concentration than common polyolefin films. Studies of migration of BHT from monolayer polyolefin films have shown that BHT has a high mobility toward fatty foods and to the environment (Wessling 
et al., 1998, 2000; Galindo-Arcega, 2004; Torres-Arreola et al., 2007). Because BHT can be used as an additive for direct addition to food (Code of Federal Regulations, $2007 \mathrm{~b}$ ), its use in active packaging has lead to commercial applications, such as in the liners for breakfast cereal packages (Yanidis 1989).

Migration is the result of the diffusion and equilibrium process involving the transfer of low molecular mass compounds (additives) from a plastic packaging into a food or food simulant. The migrants diffuse through the amorphous portion of the polymer matrix toward the interface where they are partitioned between the 2 media until their chemical potential values in both the polymer and the food reach the equilibrium. Migration is often described by Fick's second law. The theoretical background of the migration process is described by Crank (1975), Hamdani et al. (1997), and Garde et al. (2001). Till et al. (1982) reported diffusion coefficient (D) values of $3.7 \mathrm{E}-11$ and $4.2 \mathrm{E}-12 \mathrm{~cm}^{2} / \mathrm{s}$ for migration of $\mathrm{BHT}$ from a high density polyethylene (HDPE) plaque (235- $\mu \mathrm{m}$ thickness and $100 \mathrm{mg}$ of BHT/ $\mathrm{kg}$ ) to corn oil at 40 and $21^{\circ} \mathrm{C}$, respectively. Han et al. (2003) reported D values of $2.34 \mathrm{E}-11,8.65 \mathrm{E}-11$, and $2.20 \mathrm{E}-10 \mathrm{~cm}^{2} / \mathrm{s}$ for BHT in a film made of a mixture of HDPE and LDPE (30.5- $\mu \mathrm{m}$ thickness) to ethanol at 23, 31 , and $40^{\circ} \mathrm{C}$, respectively.

Monolayer LDPE films are not suitable for cheese packaging due to their high oxygen transmission rates (OTR) that accelerate the oxidation reactions. Therefore, multilayer films made of polyamide, polyethylene terephthalate, or polyvinylidene chloride are coextruded or laminated with LDPE to provide a good oxygen barrier (Robertson, 2006). These multilayer films are widely used not only for cheese packaging but for other food products like chicken breast fillets (Pettersen et al., 2004) and mussel meat (Bindu et al., 2004). Barrier properties for different multilayer packaging are reported by Lange and Wyser (2003). In the case of cheese, the use of oxygen barriers by itself does not assure the absence of lipid oxidation. Oxidation has been reported in Danboo cheese (25\% fat) packed in polyethylene terephthalate trays with an oxygen scavenger for $84 \mathrm{~d}$ at $4^{\circ} \mathrm{C}$ (Holm et al., 2006). Also, Sunesen et al. (2002) identified 28 volatile compounds in a processed cream cheese spread ( $31 \%$ fat) packed in glass flasks at 5, 20, and $37^{\circ} \mathrm{C}$ during $1 \mathrm{yr}$. Glass is one of the best barriers to oxygen.

The present work reports the development of an antioxidant active packaging consistent of coextruded films made of polyamide 6/66 (PA6/66) and LDPE added with different concentrations of BHT. The effect of heat processing on BHT concentration in the films was determined as well as the release and diffusion coefficient of $\mathrm{BHT}$ from the coextruded films to Asadero cheese.
The effect of the released BHT on cheese oxidation and odor stability was also investigated, and the compliance of the films with the legal limit established for food products was verified.

\section{MATERIALS AND METHODS}

\section{Film Manufacture}

Three formulations of LDPE (Petrothene, Equistar, Houston, TX) pellets containing 0,8 , and $14 \mathrm{mg} / \mathrm{g}$ of BHT (99\% purity, TCI America, Portland, OR) were coextruded with PA6/66 (Ultramid, BASF, Freeport, TX) by the blow extrusion process with a pilot-plant size coextruder (Beutelspacher, México DF, México) at the Centro de Investigación en Alimentación y Desarrollo, AC campus Hermosillo, México. An ethylene acrylic acid adhesive (Primacor, Dow, Midland, MI) was used to adhere the 2 layers. The $0 \%$ BHT coextruded film was used as a control. The films were labeled as 0,8 , and 14 according to the BHT added to the LDPE layer during their manufacture.

The coextruded films thickness was measured with a micrometer (model DTT, E.J. Cady \& Co., Wheeling, IL). The layers thicknesses were measured with a Carl Zeiss transmitted light microscope (Axiolab E, Thornwood, NY) equipped with a micrometer.

The OTR of the films was measured using an Oxtran 2/20 m (MOCON, Modern Controls Inc., Minneapolis, MN; ASTM D3985-95, 1995). Tests were performed at $23^{\circ} \mathrm{C}$ and expressed as $\mathrm{cm}^{3} / \mathrm{m}^{2} /$ day. Two replicates were taken at the thickest and the thinnest section of each film.

\section{Cheese Processing, Packaging, and Storage}

Asadero cheese was obtained from one batch of the standard production from the Rayón cheese factory (Rayón, Sonora, México). This brand of cheese does not contain any additive. Moisture and fat were determined according to the AOAC methods (AOAC, 2000a,b). Twenty-four blocks of cheese $(100 \pm 5 \mathrm{~g} ; 7.0 \times 10.0 \times$ $1.5 \mathrm{~cm}$ ) were packed in each of the 0,8 , and 14 films for the BHT release and oxidation experiments. Other sets of 20 blocks of cheese were packed in each of the 3 films for the sensory experiment. A vacuum sealer Loma Q NT 300/2 (Doo-Il R.S. Co. Ltd., Kyeongki-Do, South Korea) was used to obtain packages with -1 bar of pressure. The packages were stored for $100 \mathrm{~d}$ at $5 \pm$ $1^{\circ} \mathrm{C}$ and exposed to fluorescent light (fluorescent lamps platinum FO32T8; Promolux, Shawnigan Lake, Canada) with an intensity ranging between 392 and 1,396 lx (luxometer SP-840020, Neurtek Instruments, Guipuzcoa, Spain). The packages were rotated every $5 \mathrm{~d}$ to minimize the differences in light exposition. To have 
samples of fresh cheese (from the same batch) available during the experiment, enough fresh cheese was frozen at $-20^{\circ} \mathrm{C}$.

\section{BHT Release Test}

Pieces of cheese packed in films 8 and 14 were sampled at $0,3,5,20,60,80$, and $100 \mathrm{~d}$ of storage. The pieces of cheese were unpacked and BHT concentration was determined in the coextruded films as explained below. Three replicates were analyzed and results were expressed as milligrams per gram of BHT in the films. To calculate the residual BHT in the films, concentrations of BHT in samples at time 0 were compared (as percentage) with the concentration added when the films were processed. To obtain the kinetic of release, concentration of BHT in the films was plotted vs. storage time. The BHT was not quantified in the cheese because once it reaches the product, it may be lost by trapping free radicals.

Determination of BHT Concentration in the Films. Pieces of the coextruded films $(1 \times 1 \mathrm{~cm}, \sim 1 \mathrm{~g})$ were extracted with $250 \mathrm{~mL}$ of acetonitrile (JT Baker, Xalostoc, México) with constant stirring under reflux at $60^{\circ} \mathrm{C}$ for $10 \mathrm{~h}$. A second 10 -h extraction was applied to the same sample to confirm that all the BHT was extracted in the first extraction. An aliquot of the extract was used for BHT quantification. Three replicates were carried out for each sample. The BHT quantification was performed by reverse-phase HPLC using a liquid chromatograph (Varian 9012, Mexico City, México) coupled to a fluorescence detector (Varian 9075) with an excitation wavelength of $282 \mathrm{~nm}$ and an emission wavelength of $308 \mathrm{~nm}$. A $10-\mu \mathrm{L}$ sample volume was injected (Rheodyne 7125 injector) into the HPLC and eluted with methanol:water (98:2, JT Baker) at a flow rate of $1 \mathrm{~mL} / \mathrm{min}$ for $10 \mathrm{~min}$ at $25^{\circ} \mathrm{C}$ (Wessling et al., 2000; Galindo-Arcega, 2004). $\mathrm{A} \mathrm{C}_{18}$ Omnispher column $(150 \times 4.6 \mathrm{~mm}$; Varian $)$, protected with a $\mathrm{C}_{18}$ guard column $(50 \mathrm{~mm})$ was used. A calibration curve for BHT was prepared from 1 to $50 \mu \mathrm{g} / \mathrm{mL}$ solutions in acetonitrile. Concentration of BHT was expressed as milligrams per gram of coextruded film. Under these chromatographic conditions, the retention time for BHT was $3 \mathrm{~min}$. Recoveries of $83.5 \pm 1.7 \%$ were determined by spiking the control film (film 0) with BHT to achieve a concentration of $50 \mathrm{mg} / \mathrm{kg}$ followed by treatment as above. All analytical data were corrected for recoveries. The limit of quantitation (LOQ) of the procedure used in this analysis was determined to be $5.4 \mathrm{mg}$ of BHT/ $\mathrm{kg}$ in the film.

Determination of $\boldsymbol{D}$. A simplified migration model (equation 1) reported by Hamdani et al. (1997) for the beginning of the migration process was used to calculate
D of BHT from the layer of LDPE of the films 8 and 14 to the cheese. The following assumptions were considered: the BHT diffuses only to the cheese; the BHT concentration in the film decreases during contact (finite packaging); the volume of food is much larger than that of the film (cheese volume:film volume $=167.4$ ); the contact time considered is short ( $20 \mathrm{~d})$.

$$
\frac{m_{F, t}}{m_{F, \infty}}=\frac{2}{L} \sqrt{\frac{D t}{\pi}}
$$

where $m_{F, t}$ is the mass of BHT diffused to the cheese after time $\mathrm{t} ; m_{F, \infty}$ is the mass of BHT diffused to the cheese at steady state; $L$ is the thickness of the LDPE layer; $D$ is the diffusion coefficient; and $t$ is time. Values of $m_{F, t} t m_{F, \infty}$ were plotted vs. $t^{1 / 2}$ and D was calculated from the slope $\left(\mathrm{S}_{F, \infty}\right)$, according to equation 2 (Hamdani et al., 1997).

$$
\mathrm{D}=\frac{\pi}{4}\left(\mathrm{~S}_{F, \infty} \mathrm{L}\right)^{2}
$$

\section{Cheese Oxidation}

Preliminary experiments showed that THF was a volatile compound produced by cheese during storage and its production was inhibited by the direct addition of BHT. The THF was determined in cheese samples taken at $0,20,40,60,80$, and $100 \mathrm{~d}$ of storage. Each cheese sample was homogenized, and a 30-g portion was introduced to a 40-mL vial fitted with PFTE/white silicon septa (Supelco, Toluca, México) and a screw cutout top cap. Five microliters of internal standard solution [24 mg/mL of 4-methyl 2-pentanone (4M2P) Sigma, St. Louis, MO] in hexane (Sigma-Aldrich, Toluca, México) were added before heating at $90^{\circ} \mathrm{C} / 30 \mathrm{~min}$. A 25 $\mu \mathrm{L}$ volume of the headspace was taken with a gastight prewarmed syringe and injected in a Varian Star $3400 \mathrm{CX}$ gas chromatograph equipped with a flame ionization detector and a Supelcowax 10 column $(25 \mathrm{~m} \times$ $0.25 \mathrm{~mm}$ i.d., film thickness $0.25 \mu \mathrm{m}$; Supelco). The injector and detector temperatures were 220 and $200^{\circ} \mathrm{C}$, respectively. Nitrogen was used as a carrier gas at 1 $\mathrm{mL} / \mathrm{min}$, and the temperature program started at $30^{\circ} \mathrm{C} /$ $2 \mathrm{~min}$, followed by an increase to $40^{\circ} \mathrm{C}$ at $1^{\circ} \mathrm{C} / \mathrm{min}$. Then, an additional increase to $200^{\circ} \mathrm{C}$ at $10^{\circ} \mathrm{C} / \mathrm{min}$ was applied to clean the system. Three replicates were analyzed, and results were expressed as micrograms per gram of THF in the cheese. A calibration curve for THF (JT Baker) was prepared as follows: vials with $30 \mathrm{~g}$ of homogenized fresh Asadero cheese were spiked with a volume of $5 \mu \mathrm{L}$ of standard solutions to achieve concentrations from 16 to $79 \mu \mathrm{g} / \mathrm{g}$ of THF and a fix concentra- 
tion of $4 \mu \mathrm{g} / \mathrm{g}$ of $4 \mathrm{M} 2 \mathrm{P}$. The mixture was manually mixed, and the heating process was applied. The absence of THF in the fresh cheese was previously confirmed. The ratio THF/4M2P areas were plotted vs. THF concentration to obtain a linear graph. Recoveries of $111 \pm 12 \%$ were determined by spiking fresh cheese with known concentrations of THF/4M2P followed by the heating treatment described above. The LOQ of the procedure used in this analysis was determined to be $12 \mu \mathrm{g} / \mathrm{g}$ of THF in the cheese. Three replicates were analyzed for recoveries and LOQ calculations.

\section{Sensory Analysis}

Seven people were semitrained in 4 sessions for odor analysis of the cheese packed in the antioxidant films. Two references of fresh cheese and one of oxidized cheese (positive sample) were given in 10 -g portions. The oxidized cheese was obtained by irradiating a cheese sample from the same batch, with UV light for 10 min. Two General Electric 15 W G15 T8 lamps were used $(82 \%$ of the irradiance emitted in the UV-C, 250 to $280 \mathrm{~nm}$, region). The distance between the lamps and the cheese sample was $18 \mathrm{~cm}$. Panelists were asked to sniff each sample and compare it with the positive one. In a second session, the same samples (nonidentified) were given to the panelists to confirm their ability to identify the fresh and oxidized samples. Intensities were rated on a nonstructured $13 \mathrm{~cm}$ scale $(0=$ nonoxidized to $13=$ highly oxidized). Five panelists were chosen to participate in the sensory analysis. Samples of cheese packed in the 0 and 8 films and stored at $5 \pm$ $1^{\circ} \mathrm{C}$ were taken at $20,40,60,80$, and $100 \mathrm{~d}$. They were unpacked and given to the panelists in 10-g portions as in the training sessions. References of fresh (frozen at $-20^{\circ} \mathrm{C}$ ) and oxidized cheese (treated as above) were also given to the panelists in every session to refresh the nonoxidized and oxidized odor, respectively (Stone and Sidel, 1985). Two replicates were analyzed every session. The packed samples were rated on the same scale as above (Pedrero and Pangborn, 1989).

\section{Statistical Analysis}

A randomized complete block design with 2 treatments (film 0 and 8) in 5 blocks (storage time) was applied to the sensory experiment. The ANOVA was performed by ANOVA test and significant differences between the means were determined by the TukeyKramer test $(P<0.05)$ using the Number Cruncher Statistical System.
Table 1. Thickness and oxygen transmission rate (OTR) of the coextruded films fabricated of low density polyethylene [LDPE; with butylated hydroxytoluene (BHT)] and polyamide $6 / 66^{1}$

\begin{tabular}{lcc}
\hline Film & Thickness $^{2}(\mu \mathrm{m})$ & OTR $^{3}\left(\mathrm{~cm}^{3} / \mathrm{m}^{2}\right.$ per d $)$ \\
\hline 0 & $90.97 \pm 24.01$ & 24.0 to 47.0 \\
8 & $94.95 \pm 24.36$ & 21.0 to 38.0 \\
14 & $98.42 \pm 22.48$ & 26.9 to 41.3 \\
\hline
\end{tabular}

${ }^{1}$ Thickness of the LDPE layer was $43.55 \pm 9.79 \mu \mathrm{m}$. Coextruded films fabricated with 0,8 , and $14 \mathrm{mg} / \mathrm{g}$ of BHT in the LDPE layer.

${ }^{2}$ Mean \pm standard deviation of 60 replicates.

${ }^{3}$ Two replicates were analyzed for each film, the thickest and the thinnest section of the films.

\section{RESULTS AND DISCUSSION}

\section{Film Characteristics}

The thickness of films 0,8 , and 14 ranged between 91 and $98 \mu \mathrm{m}$ (Table 1). Microscopic observations showed that the thicknesses of individual layers were approximately 43,3 , and $45 \mu \mathrm{m}$ for the LDPE (BHT added), adhesive, and PA6/66 layers, respectively. The OTR values ranged from 21 to $47 \mathrm{~cm}^{3} / \mathrm{m}^{2} / \mathrm{d}$ (Table 1 ), which are considered adequate for vacuum cheese packaging (Robertson, 2006). Moreover, lower OTR values will be expected at refrigeration temperature, compared with the experimental results at $23^{\circ} \mathrm{C}$ (Dorado-Rodelo et al., 2007).

The films developed are good oxygen barriers as compared with monolayer polymer films, such as LDPE $\left(7,883 \mathrm{~cm}^{3} / \mathrm{m}^{2} /\right.$ day) for a $17.5-\mu \mathrm{m}$ film and bioriented polypropylene $\left(1,642 \mathrm{~cm}^{3} / \mathrm{m}^{2} /\right.$ day $)$ for a $29.5-\mu \mathrm{m}$ film (Soto-Valdez and Mendoza-Wilson, 1998). A PA66 monolayer film showed an OTR of $51.8 \pm 12.9$ for a 23.0 $\pm 0.5 \mu \mathrm{m}$ (Dorado-Rodelo et al., 2007). Therefore, the oxygen barrier depends on the polyamide thickness layer.

\section{Release of BHT from the Films}

BHT Concentration in the Films. The final levels of BHT in the 8 and 14 coextruded films were $3.58 \pm 0.19$ and $4.70 \pm 0.37 \mathrm{mg} / \mathrm{g}$ (Table 2 ). The BHT concentration remaining in the LDPE layer after the coextrusion process for the 8 and 14 films were $7.88 \pm 0.43$ and 10.60 $\pm 0.84 \mathrm{mg} / \mathrm{g}$, respectively. Thus, the amount of BHT lost during processing was 1.5 and $24.3 \%$, respectively. In a previous work, Galindo-Arcega (2004) reported losses of $29.7,48.8$, and $57.3 \%$ of BHT during the processing of monolayer LDPE films added with $0.5,1$, and $2 \mathrm{mg} /$ $\mathrm{g}$ of the antioxidant, respectively. It seems that the coextrusion reduces the loss of BHT as compared with the extrusion of monolayer films. Moreover, the higher the BHT added, the higher the amount lost during the extrusion process. The BHT is thermally degraded, lost 
Table 2. Effect of the fabrication process on the butylated hydroxytoluene (BHT) level in the coextruded films

\begin{tabular}{|c|c|c|c|}
\hline \multirow[b]{3}{*}{ Film $^{1}$} & \multicolumn{3}{|c|}{$\mathrm{BHT}$} \\
\hline & \multicolumn{2}{|c|}{ In the LDPE layer } & \multirow{2}{*}{$\begin{array}{l}\text { In the coextruded film } \\
(\mathrm{mg} / \mathrm{g})^{2}\end{array}$} \\
\hline & $(\mathrm{mg} / \mathrm{g})^{2}$ & $(\%)^{3}$ & \\
\hline 0 & 0 & 0 & 0 \\
\hline 8 & $7.88 \pm 0.43$ & 98.50 & $3.58 \pm 0.19$ \\
\hline 14 & $10.60 \pm 0.84$ & 75.71 & $4.70 \pm 0.37$ \\
\hline
\end{tabular}

${ }^{1}$ Coextruded films fabricated with 0,8 , and $14 \mathrm{mg} / \mathrm{g}$ of BHT in the low density polyethylene (LDPE) layer.

${ }^{2}$ Values are means \pm standard deviation of 3 replicates.

${ }^{3} \mathrm{BHT}$ remaining in the LDPE layer after processing the films.

by reaction while performing its function as an antioxidant, and also evaporated to the environment because of its high volatility at processing temperatures. It has been reported that $10 \%$ of $\mathrm{BHT}$ was volatilized during a thermal gravimetric analysis of the antioxidant at $157^{\circ} \mathrm{C}$ (Vulic et al., 2002). Temperatures up to $165^{\circ} \mathrm{C}$ were used in the LDPE extruder in the present work. The BHT may also be changed when trapping free radicals from LDPE chains during processing. Other authors reported losses of $55.5 \%$ for a LDPE film initially fabricated with $0.45 \mathrm{mg} / \mathrm{g}$ of BHT (Wessling et al., 1998). In the present work, increasing the BHT concentration added to the resin did not lead to a proportional increase in the remaining percentage of the antioxidant in the film.

\section{Release Test}

Figure 1 shows the loss of BHT from the 8 and 14 films during the storage at $5 \pm 1^{\circ} \mathrm{C}$ for $100 \mathrm{~d}$. The diffusion rates for BHT were very similar in both films. The level of the antioxidant decreased from $3.58 \pm 0.19$ and $4.70 \pm 0.37$ to $2.45 \pm 0.12$ and $3.42 \pm 0.06 \mathrm{mg} / \mathrm{g}$ during the first $3 \mathrm{~d}$ of storage for films 8 and 14 (31.6 and $27.4 \%$ of BHT released), respectively. The levels of BHT in the films after $20 \mathrm{~d}$ of contact were $1.34 \pm 0.06$ and $1.56 \pm 0.15 \mathrm{mg} / \mathrm{g}$ for film 8 and 14 (62.6 and $66.9 \%$ of original BHT), respectively. This behavior means that the antioxidant diffusion started from the first minutes of contact. From 60 to 100 d, the BHT level remained constant in both films at around $1 \mathrm{mg} / \mathrm{g}$ (72 and 78\% of $\mathrm{BHT}$ released). It is important to consider that most of the released $\mathrm{BHT}$ could be at the surface of the cheese where it is most demanded due to the effects of the light and the low oxygen level that could diffuse through the multilayer film. According to the graph, no more release of BHT from the films would be expected because it seems that the system reached equilibrium. This assumption is valid for systems in which there is no consumption of the antioxidant by radical formation as it happens in the cheese. Therefore, an increase of the diffusion of BHT from the films to the cheese would be expected after $100 \mathrm{~d}$ as the oxidation reactions proceed. Also, diffusion of the BHT from the surface to the inner part of the cheese could affect this equilibrium. A rapid decrease of $\mathrm{BHT}$ from the LDPE films into

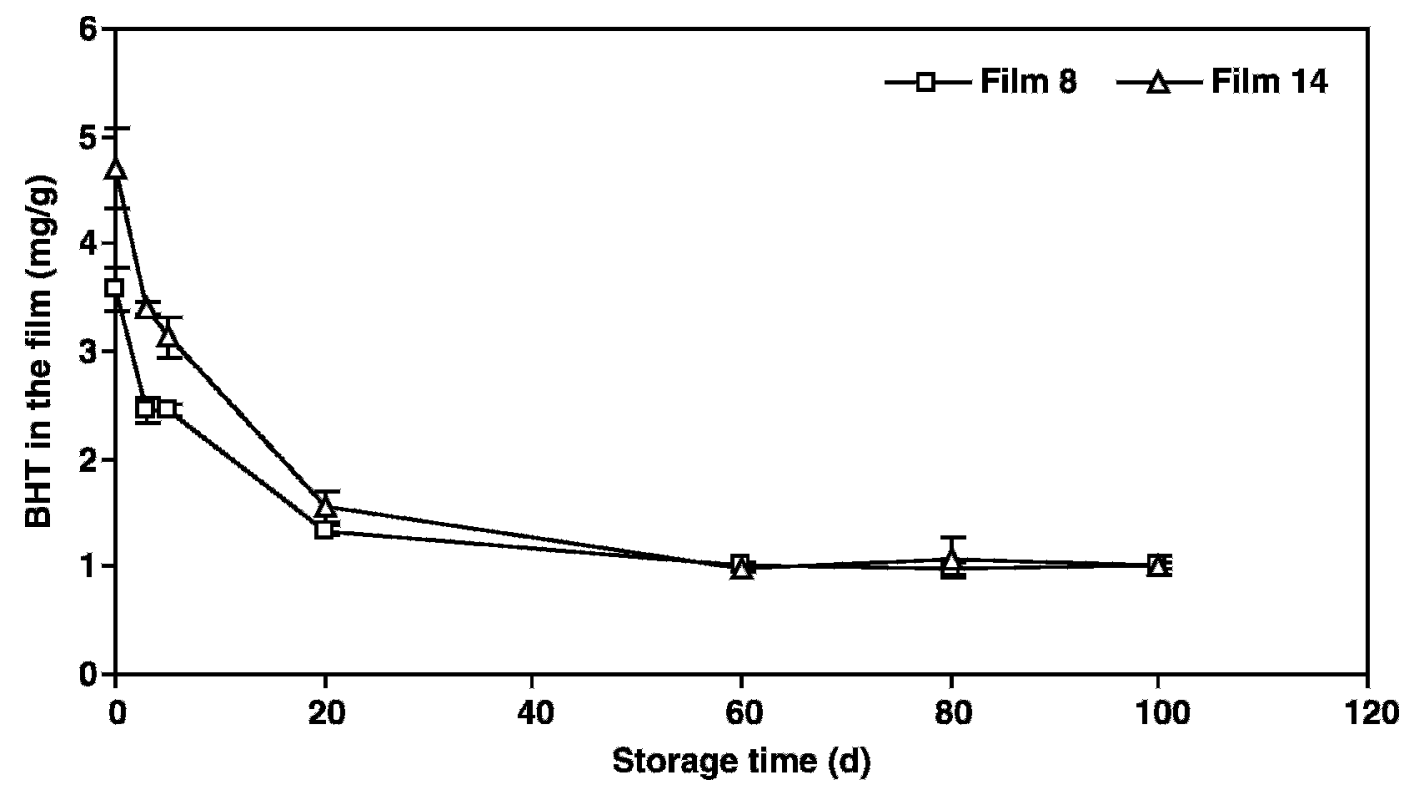

Figure 1. Decrease of butylated hydroxytoluene (BHT) from the 8 and 14 coextruded films in contact with Asadero cheese stored at $5^{\circ} \mathrm{C}$ for $100 \mathrm{~d}$. Results are means of 3 replicates. Bars indicate standard deviation. 


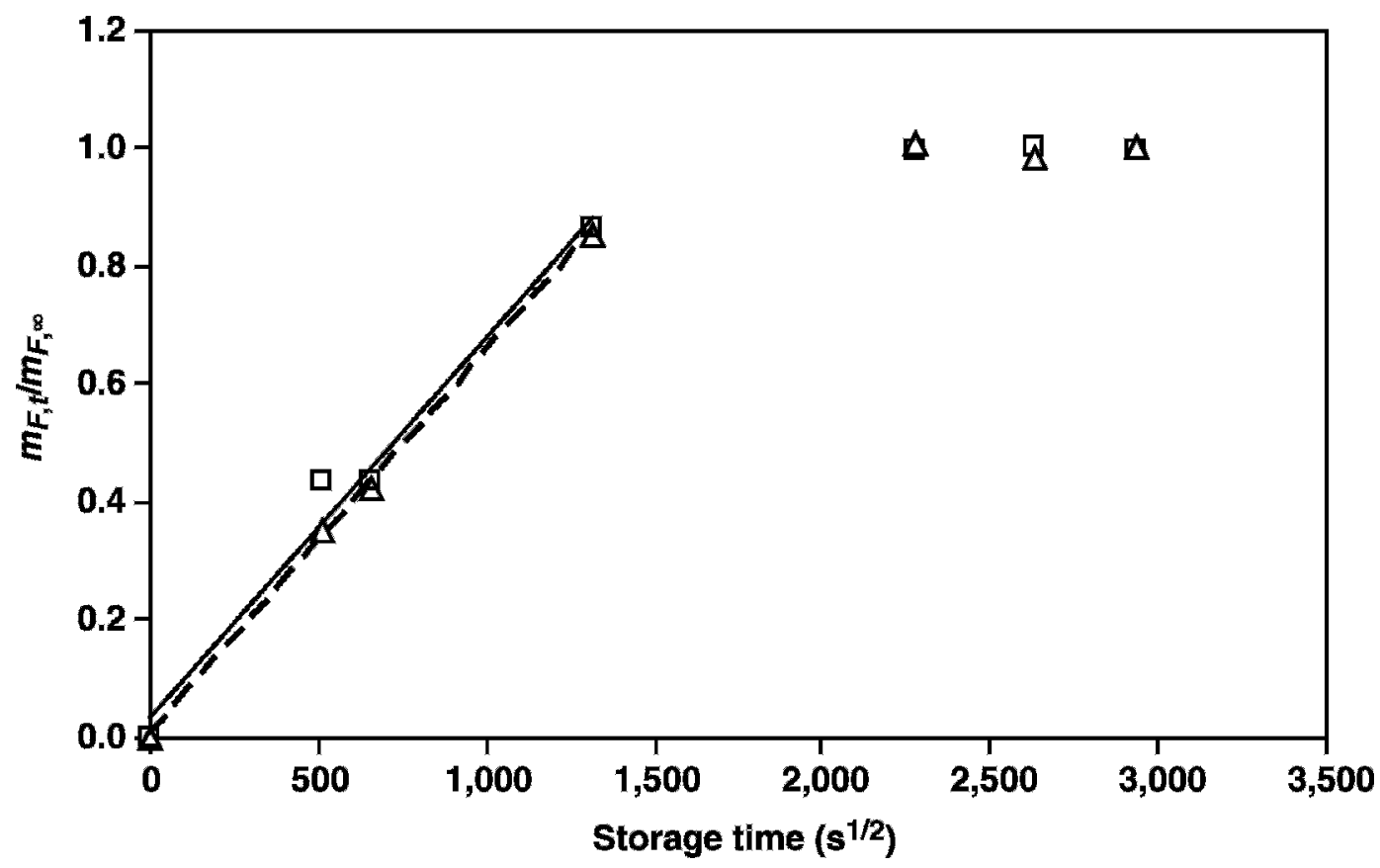

Figure 2. Determination of $D$ for the release of butylated hydroxytoluene (BHT) from films 8 ( $\square,-$ ) and 14 ( $\triangle,--)$ to Asadero cheese at $5^{\circ} \mathrm{C}$. Lines represent the diffusion of BHT to the cheese estimated by equation 1 during the first $20 \mathrm{~d}$ of contact. D values were calculated by equation 2 . Film $8(\square,-) \mathrm{y}=6.4735 \mathrm{E}-04 \mathrm{x}+3.3414 \mathrm{E}-02 . \mathrm{R}^{2}: 0.979$. D: $6.242 \mathrm{E}-12 \mathrm{~cm}^{2} / \mathrm{s}$. Film $14(\triangle,--) \mathrm{y}=6.4807 \mathrm{E}-04 \mathrm{x}+5.8151 \mathrm{E}-03$. $\mathrm{R}^{2}$ : 0.999. D: $6.256 \mathrm{E}-12 \mathrm{~cm}^{2} / \mathrm{s}$.

different foods and food simulants has been reported at different temperatures. Half of the BHT from a film $(0.85 \mathrm{mg} / \mathrm{g})$ in contact with oil was lost to the environment in less than $6 \mathrm{~h}$ at $25^{\circ} \mathrm{C}$ (Galindo-Arcega, 2004). The loss of BHT from a packaging (LDPE) for oatmeal occurred via diffusion through the material, followed by volatilization from the film surface, being sorption onto the oatmeal or diffusion to the surrounding atmosphere the final result (Wessling et al., 2000). Therefore, the rapid decrease of BHT is due to its relatively small size, rate of evaporation, solubility in fats, and high diffusion ability in the LDPE matrix.

Determination of $\boldsymbol{D}$. Figure 2 shows the diffusion graphs of BHT from the films to Asadero cheese considering the first $20 \mathrm{~d}$ of contact at $5^{\circ} \mathrm{C}$. Very similar $\mathrm{D}$ values for films 8 and 14 were calculated as $6.24 \mathrm{E}-12$ and $6.26 \mathrm{E}-12 \mathrm{~cm}^{2} / \mathrm{s}$, respectively. Limm and Hollifield (1996) reported a D of $8.3 \mathrm{E}-09 \mathrm{~cm}^{2} / \mathrm{s}$ for BHT in LDPE in contact with corn oil at $60^{\circ} \mathrm{C}$. The thousand times higher value reported is explained by a high experimental temperature $\left(55^{\circ} \mathrm{C}\right.$ higher than the cheese experiment) and also by the assumption that some components of the oil penetrated the LDPE films increasing the BHT diffusion. More similar D values (3.7E-11 and $4.2 \mathrm{E}-12 \mathrm{~cm}^{2} / \mathrm{s}$ ) were reported by Till et al. (1982) for migration of BHT from a HDPE plaque $(235-\mu \mathrm{m}$ thickness and $100 \mathrm{mg}$ of $\mathrm{BHT} / \mathrm{kg}$ ) to corn oil at 40 and $21^{\circ} \mathrm{C}$, respectively. In this case, the differences in temperatures and the higher crystallinity of HDPE contributed to the low $\mathrm{D}$ values. Crystallinity introduces tortuosity in the diffusion path of BHT through the HDPE polymer, giving similar D values when HDPE is in contact with oil at $21^{\circ} \mathrm{C}$ and LDPE with cheese at $5^{\circ} \mathrm{C}$. Most D values for BHT migration have been calculated for films in contact with liquid foods or food simulants. As expected, in the present work low values of $\mathrm{D}$ for BHT from the LDPE layer were obtained for coextruded films in contact with a solid food product under all the assumptions considered.

Compliance with Legislation. Assuming that all BHT released from films 8 and 14 migrated into the cheese during the 60 to $100 \mathrm{~d}$ of storage, concentrations of 32.2 and $49.1 \mathrm{mg}$ of BHT/kg can be estimated in the packed cheeses, respectively. Due to the diffusion equilibrium at about $1 \mathrm{mg} / \mathrm{g}$ of BHT in the films, these figures are the maximum level of the antioxidant that could have been found in the cheese. Considering the limit for the direct addition of BHT to foods is $200 \mathrm{mg} /$ $\mathrm{kg}$ of fat (Code of Federal Regulations, 2007a) and the fat proportion of the Asadero cheese used in this work was $24 \%$; the calculated legal limit of direct addition of BHT particularly to this cheese is $48 \mathrm{mg} / \mathrm{kg}$. Therefore, the BHT released by film 8 complied with this legal limit but film 14 did not. Consequently, film 14 was 


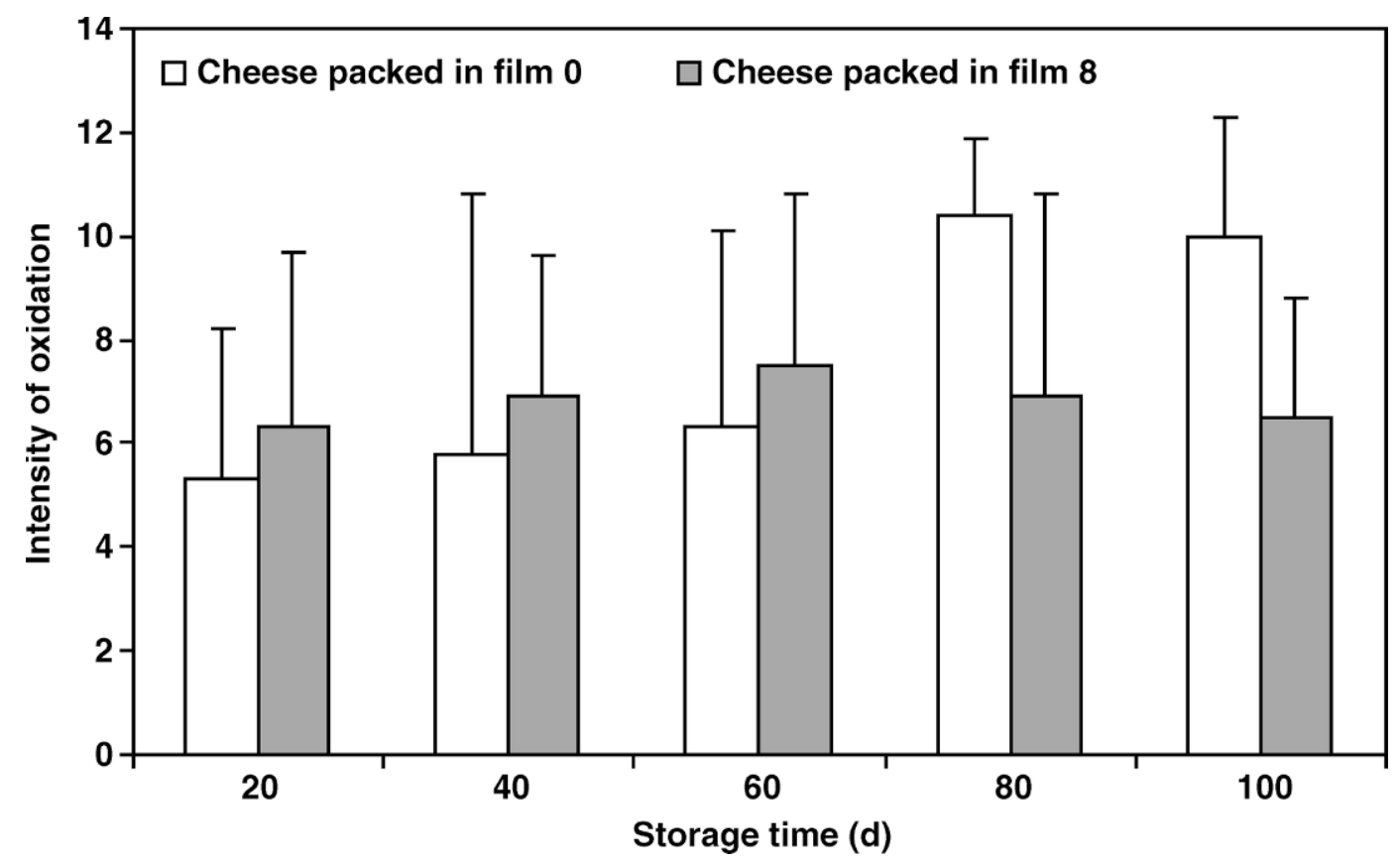

Figure 3. Oxidation intensity of Asadero cheese packed in the 8 (gray) and 0 (white) coextruded films and stored at $5^{\circ} \mathrm{C}$ for $100 \mathrm{~d}$. On the y-axis, 0 means nonoxidized and 13 means highly oxidized. Results are means of 5 panelist responses. Bars indicate standard deviation.

discarded from the sensory analysis for safety reasons. It is important to consider that in a real case, the cheese packed in the film 14 probably would never reach the $49.1 \mathrm{mg} / \mathrm{kg}$ of BHT estimated because it might have been used to trap radicals from the cheese fat portion. However, the product of this reaction is still an additive in the cheese. Therefore, this type of loss was ignored to follow a criterion to assure compliance with legislation, especially because the addition process of the antioxidant to the food was different from that for which the legal limit was established. In the case of a food product in which consumer health is involved, it is better to overestimate the BHT concentration than to underestimate it.

\section{Cheese Oxidation}

Preliminary studies (Soto-Cantú, 2007) found that THF could be used as an indicator for oxidation during the storage of antioxidant-packed Asadero cheese because its production was inhibited by the direct addition of BHT. However, in the present experiment, THF was only quantified in the cheese packed in the film 0 at 60 $\mathrm{d}$ of storage. At this time, concentrations from $<12$ to $24.5 \mu \mathrm{g} / \mathrm{g}$ of THF were quantified in a triplicate (1 replicate below the LOQ of the analytical procedure, 2 around $24.5 \mu \mathrm{g} / \mathrm{g}$ ). Samples of cheese packed in the three films at 20,40, 80, and $100 \mathrm{~d}$ of storage showed levels of THF below the LOQ of the analytical proce- dure. It is important to point out that even though the THF was found in one sampling time, it was in the cheese packed in the film with no antioxidant. In another work, Barbieri et al. (1994) identified 6 furans in 21 samples of Parmesan cheese (24 mo old), THF being one of the most abundant in the headspace of all the samples. During the storage of dairy products, formation and disappearance of volatile compounds is common due to the oxidation reactions. That could be the reason why the THF behaved as it did in the present experiment.

\section{Sensory Analysis}

Oxidation odor intensity results for cheese packed in films 0 and 8 are shown in Figure 3. Results for cheese packed in film 14 are not presented because this treatment did not comply with the BHT limit stated in the regulations (Code of Federal Regulations, 2007a) and the panelists should not have been exposed to levels of BHT higher than $200 \mathrm{mg} / \mathrm{kg}$ of the fat portion (estimated as $49.1 \mathrm{mg} / \mathrm{kg}$ of cheese in this case). The cheese packed in film 8 maintained averages of intensity of oxidized odor from 6 to 8 until the end of storage. Although there were nonsignificant differences $(P>0.05)$, the high oxidized odor detected by the panelists showed lower standard deviations at 80 and $100 \mathrm{~d}$ of storage in cheese packed in the film with no antioxidant. In other words, more panelists detected odor levels close 
to the highest oxidized level at these storage times. The oxidized odor detected at 80 and $100 \mathrm{~d}$ cannot be related to the THF found at $60 \mathrm{~d}$ of storage because this volatile compound was not found at the end of storage. The disappearance of the THF produced could be due to its reaction with other cheese components. Therefore, the oxidized odor detected by the panelists was due to the presence of other volatile compounds that unfortunately were not quantified in the present work. The THF could be produced before the first $20 \mathrm{~d}$ of storage like in the case of Samso cheese packed in modified atmosphere and stored at $5^{\circ} \mathrm{C}$ during $21 \mathrm{~d}$ (Juric et al., 2003). Future research should be directed to identify volatile products of Asadero cheese oxidation that could be correlated with the oxidized odor detected by the panelists.

\section{CONCLUSIONS}

In this work, an antioxidant active packaging was developed consisting of a layer made of LDPE to which $8 \mathrm{mg} / \mathrm{g}$ of BHT was added and coextruded with a layer of PA6/66. This active packaging was found to maintain the same levels of oxidation odor from 20 to $100 \mathrm{~d}$ of storage of Asadero cheese at $5^{\circ} \mathrm{C}$. Most of the $\mathrm{BHT}$ was diffused from the LDPE layer to the cheese during the first $20 \mathrm{~d}$ of storage at $5^{\circ} \mathrm{C}$. The release of $\mathrm{BHT}$ from the film added with $8 \mathrm{mg} / \mathrm{g}$ of the antioxidant in the LDPE layer complied with the legal limit in the cheese. However, the film added with $14 \mathrm{mg} / \mathrm{g}$ of the antioxidant in the LDPE layer could exceed that limit if all the $\mathrm{BHT}$ is released to the cheese. Therefore, a higher BHT concentration film may be needed for a more effective oxidation odor delay from Asadero cheese, but migration would exceed the legal limit of the antioxidant.

\section{ACKNOWLEDGMENTS}

This work was supported by funds from SAGARPA/ CONACYT/COFUPRO (2003 C01 095), Fundación Produce Sonora and Qualyplast (Obregón, Mexico). We are very grateful for the assistance of Jesús Villalpando Olmos, Ximena Valenzuela, Cipactli Yuridia Meza Cueto, Juan José Arreola Ordaz, and Humberto González Ríos. This work is part of the multinational project CYTED XI.21.

\section{REFERENCES}

AOAC. 2000a. AOAC Official Method 948.12 Moisture in Cheese. Pages 70-71 in Official Methods of Analysis AOAC International. 17th ed. W. Horwitz, ed. Assoc. Off. Anal. Chem. Washington, DC. AOAC. 2000b. AOAC Official Method 995.18 Fat in Cream. Pages 55-57 in Official Methods of Analysis AOAC International. 17th ed. W. Horwitz, ed. Assoc. Off. Anal. Chem., Washington, DC.

ASTM D3985-95. 1995. Standard test method for oxygen gas transmission rate through plastic film and sheeting using a colorimetric sensor. Annual Book of ASTM Standards. ASTM, Philadelphia, PA.

Barbieri, G., L. Bolzoni, M. Careri, A. Mangia, G. Parolari, S. Spagnoli, and R. Virgili. 1994. Study of the volatile fraction of Parmesan cheese. J. Agric. Food Chem. 42:1170-1176.

Bindu, J., T. K. Srinivasa Gopal, and T. S. Unnikrishnan Nair. 2004. Ready-to-eat mussel meat processed in retort pouches for the retail and export markets. Packaging Technol. Sci. 17:113-117.

Chick, J. 2002. Antioxidant delivery method. Pages 144-149 in Worldpack 2002. Improving the quality of life through packaging innovation. Vol. 1. CRC Press, Boca Raton, FL.

Code of Federal Regulations. 2007a. Title 21 Part 172. 115: Food Additives Permitted for Direct Addition to Food for Human Consumption, Subpart B-Food Preservatives. Available at http:// ecfr.gpoaccess.gov/ Accessed Oct. 28, 2007.

Code of Federal Regulations. 2007b. Title 21 Part 182. 3173: Substances Generally Recognized as Safe, Subpart D - Chemical Preservatives. Available at http://ecfr.gpoaccess.gov/ Accessed Oct. 28, 2007.

Crank, J. 1975. The Mathematics of Diffusion. 2nd ed. Oxford Sci. Publ., Oxford, UK.

Dorado-Rodelo, J. A., J. M. Ezquerra-Brawer, and H. Soto-Valdez. 2007. Effect of ovenproof plastic films on the quality of spotted rose snapper (Lutjanus guttatus) fillets during frozen storage. Packaging Technol. Sci. 20:301-307.

Galindo-Arcega, C. E. 2004. Migración del BHT de películas de PEBD y su efecto en la estabilidad del aceite de soya. MSc Thesis CIAD, AC Hermosillo, México.

Garde, J. A., R. Catalá, R. Gavara, and R. J. Hernández. 2001. Characterizing the migration of antioxidants from polypropylene into fatty food simulants. Food Addit. Contam. 18:750-762.

Hamdani, M., A. Feigenbaum, and J. M. Vergnaud. 1997. Prediction of worst case migration from packaging to food using mathematical models. Food Addit. Contam. 14:499-506.

Han, J., S. E. Selke, T. W. Downes, and B. R. Harte. 2003. Application of a computer model to evaluate the ability of plastics to act as functional barriers. Packaging Technol. Sci. 16:107-118.

Holm, V. K., G. Mortensen, M. Vichart, and M. A. Petersen. 2006. Impact of poly-lactic acid material on semi-hard cheese. Int. Dairy J. 16:931-939.

Juric, M., G. Bertelsen, G. Mortensen, and M. A. Petersen. 2003. Light-induced colour and aroma changes in sliced, modified atmosphere packaged semi-hard cheeses. Int. Dairy J. 13:239-249.

Lange, J., and Y. Wyser. 2003. Recent innovations in barrier technologies for plastic packaging-A review. Packaging Technol. Sci. 16:149-158.

Limm, W., and H. C. Hollifield. 1996. Modelling of additive diffusion in polyolefins. Food Addit. Contam. 13:949-967.

Linssen, J. P. H., J. C. E. Reitsma, and J. L. Cozijnsen. 1998. Migration of antioxidants from polyolefins into ethanolic simulants. Packaging Technol. Sci. 11:241-245.

Mortensen, G., J. Sorensen, and H. Stapelfeldt. 2002. Light-induced oxidation in semi-hard cheeses. Evaluation of methods used to determine levels of oxidation. J. Agric. Food Chem. 50:4364-4370.

Pedrero, F. D. L., and R. M. Pangborn. 1989. Evaluación Sensorial de los Alimentos Métodos Analíticos, 1st ed. Alhambra Mexicana, México D.F., México.

Pettersen, M. K., H. Nissen, T. Eie, and A. Nilsson. 2004. Effect of packaging materials and storage conditions on bacterial growth, off-odour, $\mathrm{pH}$ and colour in chicken breast fillets. Packaging Technol. Sci. 17:165-174.

Robertson, G. L. 2006. Packaging of dairy products. Pages 387-415 in Food Packaging. Principles and Practice. G. L. Robertson, 2nd ed. CRC Press, Boca Raton, FL.

Soto-Cantú, C. D. 2007. Desarrollo de un envase activo con BHT y su efecto en la autooxidación de queso Asadero. MSc Thesis CIAD, AC Hermosillo, México.

Soto-Valdez, H., and A. M. Mendoza-Wilson. 1998. Permeabilidad al oxígeno y al vapor de agua de películas plásticas utilizadas en el envasado de productos hortofrutícolas y cereales. II. Horticultura Mexicana 6:81-90. 
Stone, H., and J. L. Sidel. 1985. Sensory Evaluation Practices. Food Science and Technology. Academic Press, San Diego, CA.

Sunesen, L. O., P. Lund, J. Sorensen, and G. Holmer. 2002. Development of volatile compounds in processed cheese during storage. Lebensm.-Wiss. Technol. 35:128-134.

Till, E., D. Ehntholt, R. Reid, P. Schwartz, K. Sidman, A. Schwope, and R. Whelan. 1982. Migration of BHT antioxidant from high density polyethylene to foods simulants. Ind. Eng. Chem. Res. 21:106-113.

Torres-Arreola, W., E. Peralta, H. Soto-Valdez, J. Cárdenas-López, and M. Ezquerra-Brauer. 2007. Effect of a low density polyethylene film containing buthylated hydroxytoluene on lipid oxidation and proteins of sierra fish (Scomberomorus sierra) muscle during frozen storage. J. Agric. Food Chem. 55:6140-6146.

Urbach, G. 1993. Relations between cheese flavour and chemical composition. Int. Dairy J. 3:389-422. van Aardt, M., S. E. Duncan, J. E. Marcy, T. E. Long, S. F. O’Kefe, and S. R. Nielsen-Sims. 2005. Aroma analysis of light-exposed milk stored with and without natural and synthetic antioxidants. J. Dairy Sci. 88:881-890.

Vulic, I., G. Vitarelli, and J. Zenner. 2002. Structure-property relationships: Phenolic antioxidants with high efficiency and low color contribution. Polym. Degrad. Stab. 78:27-34.

Wessling, C., T. Nielsen, and J. R. Giacin. 2000. Antioxidant ability of BHT- and $\alpha$-tocopherol-impregnated LDPE film in packaging of oatmeal. J. Sci. Food Agric. 81:194-201.

Wessling, C., T. Nielsen, A. Leufvén, and M. Jägerstad. 1998. Mobility of $\alpha$-tocopherol and BHT in LDPE in contact with fatty food simulants. Food Addit. Contam. 15:709-715.

Yanidis, A., inventor. 1989. Flexible packaging material containing an antioxidant. James River II Inc., assignee. US patent $4,889,696$ 